\title{
INFLUENCE ON THE ENVIRONMENT OF THE FLOOD PROTECTION MEASURES ON THE DNISTER RIVER NEAR SAMBIR (LVIV REGION)
}

\author{
Andriy Mykhnovych \\ Ivan Franko National University of Lviv, \\ P. Doroshenko St., 41, UA - 79007 Lviv, Ukraine, \\ e-mail:2andira@ukr.net
}

The object of study is the environment within the territory of the dikes, sluices, pipe water passes, riverbank walls constructing and other hydrotechnical measures in the Upper Dnister valley and its left tributary Chukivka (Oreb) near Sambir. The aim of the study is the analysis of the possible expected impacts on the environment of constructing and exploitation of hydrotechnical buildings in Ralivka and Zadnistrya villages (southern Sambir suburb). The main methods of research are field investigation, mapping, photofixation, cartographical and statistical analyses. The input data are technical characteristics of the planed objects and measures, profile departmental information on the environmental components and ecosystems state. The information about the Dnister riverbed state, the character of the riverbed processes, erosion have been worked out. The resistance of different components of the environment against the planned measures and hydrotechnical building is analyzed. As the results of research, some recommendations and protective measures for minimization of negative ecological effects for floodplain and riverbed ecosystems have been substantiated. During the first year, the intensive sheet erosion is predicted and sediments runoff will increase during the intensive rain. Also, the local air temperature will increase. Temporary local climate changes can negatively impact on some biological species of the bank ecosystem. By degrees, the riverbank will be renewed in natural vegetation and local climate changes will become weaker. In the riverbed and floodplain, some reformation of the cross-sections and the riverbed relief forms will occur. So, the sediments balance in the Dnister and Chukivka riverbeds will be changed. In consequence of these processes, the sediments runoff will considerably increase in the Dnister downstream. The planed activity and described processes will not have considerable negative effects upon the flood plain and river valley biotopes. It is important for biodiversity and landscape diversity saving.

Key words: flood protection, inundation, riverbed, floodplain, dikes, hydrotechnical engineering, regulating, Dnister River.

Power and frequency of the flood events in the Carpathian region noticeably increased last decades. Due to flood development hundreds of people have died, thousands of buildings and hundreds kilometers of communications have been destroyed. Oftenest the settlements in the river valleys of Dnister and its right tributaries are affected. Therefore, the problems of flood management and flood risk mitigation are urgent and actual in the region. Last decades several times also southern suburb of Sambir has been flooded.

Hydrologic regime, geological-geomorphologic structure of the river valley, hydraulic and river course parameters, level of economical activity and man-made effects (dike, sluices, channels constructing, riverbed strengthening, drainage etc) determine the trends and intensity of

(C) Mykhnovych A., 2019

Ә Open Access (сc) BY публічної ліцензії Creative Commons "Із зазначенням авторства - 4.0 міжнародна" 
erosion-accumulation transformation of transversal and longitudinal profiles of the riverbeds as well as flood water levels and dike braking risk. Investigation of these aspects is especially urgent for the premountain river valleys such the Upper Dnister. Information about water surface and bottom inclination, cross-section area, stream width, roughness factor, and other parameters allow to asses a water passing capability, evaluate the flood risk and ascertain the regime of floodplain flooding for different probability events. Therefore, these researches are the base of effective flood protection and processes regulation measures implementation as well as forecasting of the potential influences upon environment.

The object of study is environment within the territory of the dikes, sluices, pipe water passes, riverbank walls constructing and other hydrotechnical measures in the Upper Dnister valley and its left tributary Chukivka (Oreb) near Sambir.

The aim of the study is analysis of the possible expected impacts on environment of constructing and exploitation of hydrotechnical buildings in Ralivka and Zadnistrya villages (southern Sambir suburb). The main methods of research are field investigation, mapping, photofixation, cartographical and statistical analyses. The input data are technical characteristics of the planed objects and measures, profile departmental information on the environmental components and ecosystems state.

The forecasting of man-made effects and influences of the planed works on the environment state is carried out as prediction of stable changes in the geosystems due to combined chain reactions which are caused by direct and indirect natural and manmade factors. Three kinds of projections are taking into account: short-term and seasonal ones - up to 1-2 years, mediumterm $-2-10$ years and long-term ones - more than 10 years. The following predictions were worked out for Sambir area: 1) projections of impacts and effects on the environment substantiated forecasting of the kinds, ways and factors of the impacts on the geosystems during building works and exploitation of the constructed objects and engineering; 2) projections of the environment components reactions - forecasting of these components changes due to direct and indirect impacts of natural and manmade factors; 3) projection of environment changes substantiated stable integral changes in the environment under combined impact of all factors.

The methods of expert evaluation, modeling, statistic, GIS-modeling have been used. Potential influences on the flora and fauna species have been studied by the methods of strip survey. Topographic maps of 1:25 000 i 1:10 000 scales have been used. The birds were observed in typical biotopes in evening hours.

Concerning hydrographic and flood parameters and aspects the riverbed and flood plain crosssections, longitudinal profiles, water level, water and sediments runoff data were systemized and analyzed. The data on erosion and accumulation processes have been worked out to predict riverbed bottom erosion and accumulation intensity, flood risk evaluation etc.

The information and results of field investigation have been used as well as the data obtained by the engineering-topographic investigation of the Scientific-project Institute "Lvivdiprovodhosp" in June 2017, the results of the engineering-geological investigations carried out by the Lviv Hydrogeologic-Meliorative Expedition, hydrological calculations of Volodymyr Chornyi, statistical data of the State Committee of Hydrometeorology, Lviv Regional Water Resources Management Authority.

The studied area is located within the riverbed and right side floodplain of the Dnister River upstream and downstream from the Chukivka mouth (southern suburbs of Sambir, Lviv region) (see figure). 


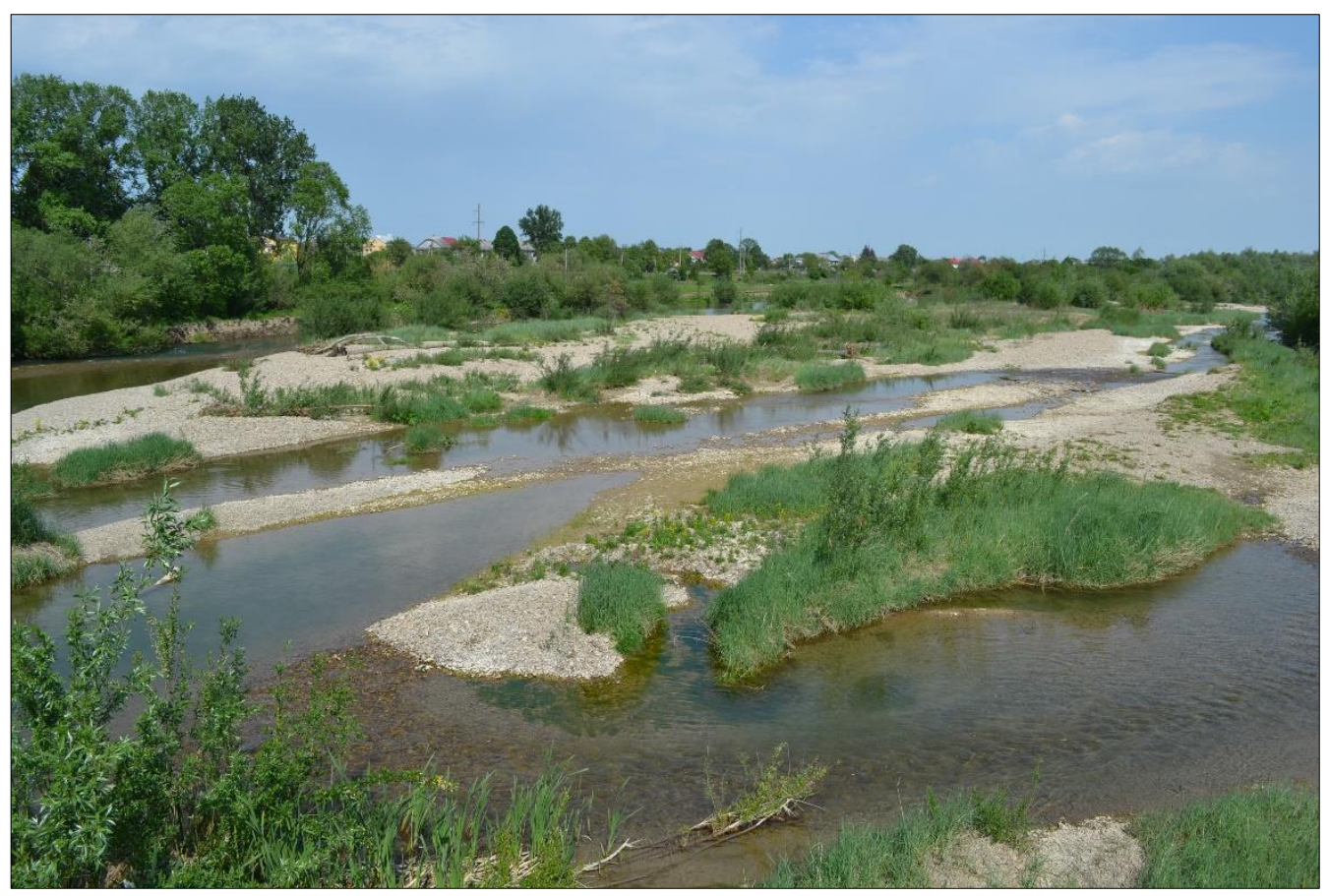

The nature of the Dnister riverbed in the studied area

Характер русла Дністра на ділянці досліджень

In the Precarpathians, the Dnister riverbed fluctuates. The flow velocity is about $0.7 \mathrm{~m} / \mathrm{s}$. The riverbed sediments are presented by gravel and boulders. The riverbed width is $9-20 \mathrm{~m}$, the average depth is $0.5-1.2 \mathrm{~m}$. The riverbed is meandering, somewhere furcated, with small islands of $0.2-1 \mathrm{~m}$ height, strongly deformed, especially during the floods. The floodplain is bilateral. The bank height changes from 1 to $2.5 \mathrm{~m}$. The floodplain is covered by meadows, shrubs.

Water runoff has noticeable flood regime. Spring flood starts in March and is characterized by quick water level raise (up to $1.5-2.5 \mathrm{~m}$ /day). Water level usually increases on 1-2.5 m, sometimes up to 3-4 $\mathrm{m}$. The river is characterized by very unstable flood regime. During the flash floods, the water level amounts 4-5.5 m (water raising velocity reaches $1.7-3.5 \mathrm{~m} /$ day and more).

Analysis of the previous investigations results testifies about tendency to decreasing of riverbed bottom due to long-term exploitation of the gravel pit near Torchynovychi village resulting in regressive erosion.

The Dnister in study site flows in the gray area between mountain and premountain segments of the river valley, where flood waters often walks out on the floodplain [2]. Important feature of geological structure of the Upper Dnister basin is lack of crystalline rocks. Paleogene and Neogene sediments dominate in the study area (argillites, siltstones, conglomerates, salts, clays, sandstones). Low terraces are covered by quaternary alluvial sediments presented by sand, gravel and pebble with low filtration ability. Present-day vegetation is presented by forests, meadows and riverside vegetation and idle lands. 
The sources of potential impact on environment: 1) the right-bank dike on the Dnister floodplain in Ralivka and Zadnistrya villages of $2700 \mathrm{~m}$ length up and downstreamm of the Chukivka (Oreb) mouth; 2) the right and left-bank dikes of 1540 m length in the Chukivka (Oreb) mouth; 3) digging of total volume $116100 \mathrm{~m}^{3}$, including $58500 \mathrm{~m}^{3}$ excavation and $57600 \mathrm{~m}^{3}$ mound; 4) retaining walls of $720 \mathrm{~m}$ length (concrete) with total volume $694.2 \mathrm{~m}^{3}$; 5) the Chukivka riverbed regulating and $942 \mathrm{~m}$ length riverbanks straightening of the Chukivka and the Dnister riverbanks by stones $\left(206 \mathrm{~m}^{3}\right.$ (Chukivka) and $3751 \mathrm{~m}^{3}$ (Dnister) and gravel (132 $\mathrm{m}^{3}$ (Chukivka) and $51 \mathrm{~m}^{3}$ (Dnister); 6) hydrotechnical engineering (27 concrete pipes for passing $\left(44.82 \mathrm{~m}^{3}\right)$, 235 concrete plates $\left(65.4 \mathrm{~m}^{3}\right)$, reinforced concrete $\left(103.6 \mathrm{~m}^{3}\right)$, stones $\left.\left(117.3 \mathrm{~m}^{3}\right) ; 7\right)$ new and renewed water discharge constructions with 4 reinforced concrete pipes $\varnothing 1.0 \mathrm{~m}\left(7.6 \mathrm{~m}^{3}\right)$, 7 reinforced concrete pipes $\varnothing 0.4$ м $\left(2.66 \mathrm{~m}^{3}\right), 43$ concrete plates $\left(10.2 \mathrm{~m}^{3}\right)$, monolith concrete $\left(34.2 \mathrm{~m}^{3}\right), 7$ check valves and 1 dumper; 8) building works; 9) vegetation cutting in $30 \mathrm{~m}$ belt along river; 10) cutting and deterioration of the soil cover during building works; 11) heavy machines using.

The planed activities and works will have direct influence on the water levels, water and sediments runoff, riverbed processes and relief, water flow velocity, hydrodynamic parameters, soils and vegetation cover of the floodplain, erosion and accumulation intensity in the riverbed and the floodplain, flood risk, biodiversity, hydroecological state of the Dnister River floodplainriverbed ecosystems near Sambir (villages Ralivka and Zadnisrya).

The new dikes constructing is planed to prevent flooding agricultural fields, settlements and communications. The dike top will be $1 \mathrm{~m}$ higher than 100 years probability flood level. The width of the dike top $-4 \mathrm{~m}$. Total width of the constructing works belt is about $30 \mathrm{~m}$. Projected bank strengthening will protect new dikes and bank sections against intensive erosion during the floods when water level increases $1.5-2 \mathrm{~m}$ and flow velocity amounts $3-3.5 \mathrm{~m} / \mathrm{s}$.

Constructing works will be accompanied by vegetation cutting and soil cover destruction on $30 \mathrm{~m}$ belt. Alternative method of anti-flood protection on the studied area is the dike of another construction (stone and waterproof screen). Another alternative is constructing small water reservoirs in the mountains and so called dry water accumulative reservoirs.

In the natural conditions of the river functioning even by low flow velocity we can observe permanent riverbed deformations moving upstream and downstream. Therefore, it is necessary to arrange stream regulating constructions. They can be placed directly at the banks or within the floodplain. According to the classification [1] they are divided into longitudinal and transversal regarding to water flow direction. Also the spurs and semi-dams can be used. The spurs and semidams are separately located constructions, which penetrate deep into water flow. The main feature of the semi-dams is providing conditions for the new riverbank forming in some period of time. The new bank is formed by sediments accumulation. The experience testifies that semi-dams parallel located on defined distance each other are as effective as the dikes constructing. Changing dikes into semi-dams is advisable because in this case the banks renewing takes place in natural conditions. Moreover, beside this the semi-dams can be easy lengthened and built up. However, the short semi-dams are not useful by the caving banks. So by the convex riverbanks it is advisably to construct the semi-dams, and by the caving ones - the dikes [1].

Calculated water discharge of $1 \%$ probability is $1130 \mathrm{~m}^{3} / \mathrm{s}$ for the Dnister and $84.4 \mathrm{~m}^{3} / \mathrm{s}$ for the Chukivka (Oreb) River. According to the project, the dike of total length $2706 \mathrm{~m}$ is renewed and finished along the Dnister and the new $1542 \mathrm{~m}$ dike is constructed along the Chukivka River. Levels of the dike top are $1 \mathrm{~m}$ above $1 \%$ probability flood for the Dnister and $0.5 \mathrm{~m}-$ for the Chukivka. 
For the existing dike accretion the vegetation and soil cover will be cut to $0.15 \mathrm{~m}$ depth along the top and slopes. New dikes is built on the new course and are constructed of local ground layer by layer $(20-30 \mathrm{~cm})$ with compression $\left(\rho=1.95 \mathrm{~g} / \mathrm{cm}^{3}\right)$ by optimal humidity. The dike width on the top is $4.0 \mathrm{~m}$. The slopes: lower $-1: 2$, upper $-1: 2.5$. Destroyed by the flood of 2014 is reconstructed on the length $220 \mathrm{~m}$ as well as five semi-dikes.

Water runoff from the dike area is provided by water outlets of $1.0 \mathrm{~m}$ diameter with check valves. The dike slopes are strengthened by the retaining walls made of reinforced concrete with overall length about $700 \mathrm{~m}$.

Influences on the environment. During first year, the intensive sheet erosion will be observed and sediments runoff will increase during the intensive rain. Also the local air temperature will increase. Local deforestation and shrubs cutting will cause stronger winds on the area. Temporary local climate changes can negatively impact on some biological species of the bank ecosystem. By degrees the riverbank will be renewed in natural vegetation and local climate changes will be weakly noticeable.

As the structural materials the local gravel-pebble sediments are used. By moving of these materials from one bank to another their granulometry and density are changed. However, it has not noticeable environmental effects. In the riverbed and floodplain some reformation of the cross-sections and the riverbed relief forms will occur. Therefore, the sediments balance in the Dnister and Chukivka riverbeds will be changed. In consequence of these processes the sediments runoff will considerably increase in the Dnister downstream. Increasing sediments runoff will cause accumulation intensification downstream including Upper Dnister Lowland. Also the granulometry of sediments will be changed. The planed activity and described processes will not have considerable negative effects upon the flood plain and river valley biotopes which are important for biodiversity and landscape diversity saving.

Conclusions and recommendations

1. There will be no any noticeable negative effects on the rare species on the area. The geomorphologic, climatic and hydrologic changes will be temporary in general. From the nature protection point of view, it is very important the choice of right methods and facilities of the hydrotechnical works. The proposed hydrotechnical measures will provide regulating riverbed erosion-accumulation processes intensity and allow supporting the natural state of the riverbed and floodplain ecosystems.

2. All building and technical works have to be carried out in summer and autumn periods to avoid danger for animals during fertile period.

3. According to the Article 88 of Water Code of Ukraine [3] along the river course of the Dnister riverbank protective belt has to be set with $100 \mathrm{~m}$ width and for the Chukivka the width of this belt $-25 \mathrm{~m}$. External border of these belts are limited by the dikes slopes.

4. To avoid the pollution of water and soils within the riverbed and floodplain by the building machinery it is necessary to provide right exploitation and permanent monitoring of the technical state.

5. For risk mitigation of the dikes breaking and hurting the exploitation service has to regularly monitor technical state of the dikes and retaining walls.

6. Water runoff increase in whole region including the Upper Dnister basin will advantage to increase flood discharges in future. Erosional cutting of the regional rivers will provide the sediments runoff increase and their accumulation within the riverbed and floodplain complex downstream. These processes can threaten to excess the flood level of $1 \%$ probability over the calculated ones and enhance the risk of the dike breaks and overflooding. 


\title{
СПИСОК ВИКОРИСТАНОЇ ЛІТЕРАТУРИ
}

1. Гірські автомобільні дороги Українських Карпат: Аналіз пошкоджень паводком 1998 року автомобільних доріг Закарпаття і рекомендації щодо попередження руйнувань гірських автомобільних доріг Українських Карпат / за ред. В. О. Герасимчука. Ужгород: Закарпаття, 2000. 272 с.

2. Природа Львівської області / за ред. К. Геренчука. Львів: Вища школа, 1972. 152 с.

3. Водний кодекс України // Відомості Верховної Ради України від 13.06.1995. 1995. № 24. ст. 189.

\section{REFERENCES}

1. Herasymchuk, V. (Ed.) (2000). Mountain roads of the Ukrainian Carpathians. Analysis of the damages of the roads in Transcarpathian region caused by the flood of 1998 and recommendations on prevention of the mountain roads damages in the Ukrainian Carpathians. Uzhhorod, 272 pp. (in Ukrainian).

2. Herenchuk, K. (1972). Nature of Lviv region. Lviv, 152 pp. (in Ukrainian).

3. Water Code of Ukraine (July 13, 1995). Bulletin of the Parliament of Ukraine, 24(article 189) (in Ukrainian).

Стаття: надійшла до редакиії 27.09.2019

доопраџьована 11.11.2019

прийнята до друку 29.11.2019

\section{ВПЛИВ НА ДОВКІЛЛЯ ПРОТИПАВОДКОВИХ СПОРУД НА Р. ДНІСТЕР В РАЙОНІ САМБОРА (ЛЬВІВСЬКА ОБЛАСТЬ)}

\author{
Андрій Михнович \\ Львівський національний університет імені Івана Франка, \\ вул. П. Дороченка, 41, 79007, м. Львів, Україна, \\ e-mail:2andira@ukr.net
}

Об'єкт дослідження - компоненти довкілля в зонах спорудження захисних дамб, підпірних стінок, регулювання русла р. Чуківка і Дністер. Метою досліджень $\epsilon$ аналіз можливих і очікуваних впливів запланованої діяльності і гідротехнічних споруд у селах Ралівка і Задністр'я (південні околиці м. Самбір) на компоненти довкілля. Головні методи досліджень: польові обстеження, картування, фотофіксації, картографічного аналізу, аналізу літературних та фондових джерел. Вихідні дані: технічні характеристики проектованих об'єктів і споруд. У ході досліджень опрацьовано дані про стан русла, характер руслових процесів, стан рослинного покриву на ділянці спорудження, схарактеризована стійкість русла до ерозійної діяльності водного потоку, проаналізовано вплив гідротехнічних робіт на різні компоненти довкілля річкової долини. У результаті виконаних робіт запропоновано заходи, спрямовані на мінімізацію шкідливого впливу та екологічних наслідків для заплавно-руслового комплексу річки та його екосистеми. Щодо екологічних наслідків, у перший рік відсутність рослинності на ділянках робіт призведе до збільшення поверхневого стоку в русло під час інтенсивних дощів, а також до швидшого і сильнішого нагрівання поверхні берега $і$ заплави, неприкритих рослинністю. Це призведе до тимчасових змін мікроклімату, які можуть негативно позначитися на окремих представниках рослинного і тваринного світу берегової екосистеми. Однак 
Influence on the environment of the flood protection measures ...

3 плином часу берег відновлюватиме свою природну рослинність, мікрокліматичні зміни ставатимуть щоразу менш помітними. У процесі виконання робіт очікується переформування поперечного профілю і трансформація руслових форм рельєфу. Оскільки використовуватиметься піщаногравійний і гальково-валунний матеріал руслового алювію, то змін зазнає баланс наносів і відкладів у річковій системі. Збільшиться каламутність потоку і витрата наносів у руслі Дністра нижче за течією. Спорудження дамб, кріплень відкосів та берегоукріплень не вплине суттєво на стан заплавно-долинних біотопів ріки, які $є$ важливими для різноманітності і чисельності популяцій рідкісних і цінних видів.

Ключові слова: протипаводковий захист, затоплення, русло, заплава, дамба, гідротехнічні споруди, регулювання, Дністер. 